Article

\title{
Daytime Lighting Assessment in Textile Factories Using Connected Windows in Slovakia: A Case Study
}

\author{
Dušan Katunský ${ }^{1, *(1)}$, Erika Dolníková ${ }^{2}$ and Bystrík Dolník ${ }^{3}$ \\ 1 Department of Architecture and Building Structures, Institute of Architectural Engineering, \\ Faculty of Civil Engineering, Technical University of Kosice, 04020 Kosice, Slovakia \\ 2 Department of Building Physics, Institute of Architectural Engineering, Faculty of Civil Engineering, \\ Technical University of Kosice, 04020 Kosice, Slovakia; erika.dolnikova@tuke.sk \\ 3 Department of Electric Power Engineering, Faculty of Electrical Engineering and Informatics, \\ Technical University of Kosice, 04020 Kosice, Slovakia; bystrik.dolnik@tuke.sk \\ * Correspondence: dusan.katunsky@tuke.sk; Tel.: +421-055-602-4157
}

Received: 26 November 2017; Accepted: 23 February 2018; Published: 28 February 2018

\begin{abstract}
This paper highlights the problems that are associated with daylight use in industrial facilities. In a case study of a multi-story textile factory, we report how to evaluate daylight (as part of integral light) in the production halls marked F and G. This study follows the article in the Buildings journal, where Hall E was evaluated (unilateral daylight). These two additional halls have large areas that are $54 \times 54 \mathrm{~m}$ and are more than five meters high. The daylight is only on the side through the attached windows in envelope structures in the vertical position on the hall. In this paper, we want to present two case studies of these two production halls in a textile factory in the eastern part of Slovakia. These are halls that are illuminated by daylight from two sides through exterior peripheral walls that are against or next to each other. The results of the case studies can be applied in similar production halls illuminated by a "double-sided" (bilateral) daylight system. This means that they are illuminated by natural illumination through windows on two sides in a vertical position. Such a situation is typical for multi-storied industrial buildings. The proposed approximate calculation method for the daylight factor can be used to predict the daylight in similar spaces in other similar buildings.
\end{abstract}

Keywords: sustainable architecture; industrial building; indoor environment; lighting conditions; computational simulation; luminance

\section{Introduction}

Many authors deal with daylight systems. An active solar daylighting system behind the perimeter wall is described by Kontadakis, A. et al. [1]. Furthermore, Tsangrassoulis, A. et al. [2] deals with the prototype of the hybrid daylight system. Some other aspects play important roles for daylight, such as dimming in relation to daylight (Doulos, L. et al. [3]). Doulos, L. et al. [4] also describes the role of the spectral response of photosensors in daylight response systems. One of the well-known authors dealing with daylighting and its impact on building users is Belia, L. [5,6].

The influence of daylight during the daytime on human health was studied by Shishegar, N. et al. [7] and Friborg, O. et al. [8]. Daylight affects the physiological and biological processes in the human body (McColl, S.L. et al. [9] and Smolders, K.C. et al. [10]), as well as the visual perception of interiors (Yao, J. et al. [11] and Fabi, V. et al. [12]). Gou, Z. et al. studied the visual comfort and light simulated effects in relation to workers' productivity and well-being [13,14]. Daily lighting and its visual and non-visual perceptions of the indoor environment impacts the performance of people in the building. Research on the nonvisual daytime light effects on humans in buildings for non-visual health potentials, visual interest and observed behaviour is found in the work by Amundadottir, M. L. et al. [15] and visual perception (Lee, J. H. et al. [16]). Direct sunlight and its effects are investigated by Wang, N. et al. [17], 
Yokoya, M. et al. [18], and Lee, K.S. et al. [19]. A barrier to dazzle and unpleasant dazzling is described by Hirning, M.B. et al. [20,21]. Shen monitors a model containing a synchronized daylight shadow operation with simplified control (Shen, H. \& Tzempelikos, A. [22]). Research in this field is also focused on the different types of microclimates, as well as on the overall assessment of the internal environment (Švajlenka, J. et al. [23,24]).

Building design, depending on the daylight, is described in the book Handbook for Architects and Engineers (Baker, M. and Steemers, K. [25]). Industrial buildings have certain features when designing lighting. This problem is addressed in the book Handbook of Industrial Lighting (Lyons, L.S. [26]). A whole range of problems related to the design of lighting openings in industrial buildings has been described by Dolniková, E. and Katunský, D. [27]. The problem that is associated with designing and evaluating windows in terms of daylight lighting is given by Kalousek, M. and Mohelníková, J. [28].

In terms of indoor lighting, various types of buildings that require demanding visual activities are examined in the literature. Educational buildings and schools are dealt with by Ferencikova, M. and Darula, S. [29], Moazzeni, M.H. et al. [30], Kruger, E.L. et al. [31], Piderit Moreno, M.B. et al. [32], and others. Residential buildings are followed by Xue, P. et al. [33], Nebia, B. et al. [34]; apartment buildings by Iringova, A. [35]; atrium building by Mohsenin, M. et al. [36], and office buildings by Berrardi, U. et al. [37], Gonzales, J. et al. [38], Pellegrino, A. et al. [39], Costanzo, V. et al. [40], and Konis, K. [41].

Different types of light or lighting are the sum of the research activities of the team (Mistrick, R. et al. [42]), which deals with computer modelling of the photocontrols of electric lighting systems that are integrated daily. The simulation and modelling of daylight are analysed by Nasrollahi, N. et al. [43]. The energy efficiency of light is monitored by Reinhart, C.F. et al. [44]. The use of daylight when confronted with cold LED illumination is described by Amorim, R. et al. [45], the energy and visual control is described by Shen, E. et al. [46], and the lateral and visible atmosphere is described by Uriarte, U. et al. [47]. Adaptive light is tracked by Gunay, H.B. et al. [48] and a simulation to visualize and debug the behaviour of the lighting regulator is done by Jia, L. et al. [49]. An analysis of several criteria for selecting the optimal position and the correct field of view of the photosensor that is required in a building as well as the quantification of energy savings in daylight response systems in the dimming function of electronic ballasts is studied by Doulos, L. et al. [50,51]. Chromaticity-matched, but spectrally different, light effects sources on simple and complex colour judgments are studied by Veitch, J.A. et al. [52]. The meteorological models of the distribution of the brightness of the sky of external lighting and the approximate configuration and validation of the sky were studied by Perez, R. [53] and Igawa, N. [54].

As a result, daylight is very important in industrial halls for visual convenience. Especially for human vision and circadian rhythms, this is very important and effectively stimulates them. Unless we take into account all of the needs and benefits, daylight can affect visual performance. It can cause discomfort by dazzling eyes and cause unpleasant scattering in the interior. Daylight may also weaken performance by creating shadows in the workplace. The effectiveness of electrical artificial lighting during the daylight depends on the quality of the light sources and their similarity to the radiation of daylight. Therefore, the negative aspects are also positive in daylight. Integral lighting is dealt with and certain conditions are proposed by Katunský D. [55]. Lighting conditions at the workplaces were examined using both practical and mathematical methods by Van Bommel, W.J.M. and van den Beld, G.J. [56]. The influence of user behaviour on unsatisfactory indoor thermal environments is described by Yan, B. et al. [57].

The incorporation of methods of daylight assessment into urbanization was studied by Sokol, N. and Martyniuk-Peczek, J. [58] and Chen, K.W. and Norford, L. [59]. These considerations have motivated us to do this research into daylight systems in order to improve the quality and comfort of interiors for workers, while reducing energy consumption. The study of six industrial halls in France was published by Labat, M. and Attonaty, K. [60]. A similar problem in the industry is also addressed by Gourlis, G. and Ivacic, I. [61] and Pham, K. et al. [62].

One of the first to focus on the assessment of the impact of industrial buildings on the environment in terms of their sustainability is Alarcon, B. et al., [63]. The effectiveness of lighting in 
an industrial factory (a case study in Slovakia) was examined by Katunský, D. et al. [64]. New models for sustainability assessment criteria in industrial buildings have been developed (Lombera, J.T. and Rojo, J.C. [65]). The modified criteria for the assessment of the sustainability of industrial buildings have resulted in the development of new models by Lombera, J.T. and Aprea, I.G. [66]. In this text, we want to outline the continuation of research tha is aimed at ensuring minimal daylight conditions throughout the day in large-scale floor plans.

\section{The Aim of the Research}

In the design, construction, and operation of manufacturing buildings, it is necessary to consider the requirements for the sustainability of the buildings. Specifically, we are interested in the microclimate of the interior of industrial buildings, focusing on the indoor light microclimate, the thermal humidity, and other factors, with an emphasis on energy saving in operation. Last but not least, is building sustainability. The design requirements for the construction and operation of production facilities should consider the requirements in order to achieve sustainability. In particular, we are interested in the indoor climate in the interior of industrial buildings, focusing on indoor light, acoustic, thermal-humidity and other types of microclimates with an emphasis on energy saving aimed at building sustainability conditions.

An industrial building must be environmentally relevant, economically efficient, with stately architecture so that it leads to sustainability even within the industry (see Figure 1). In this paper, we are primarily concerned with the daytime lighting through window constructions and indoor environments and the lighting conditions in industrial buildings.

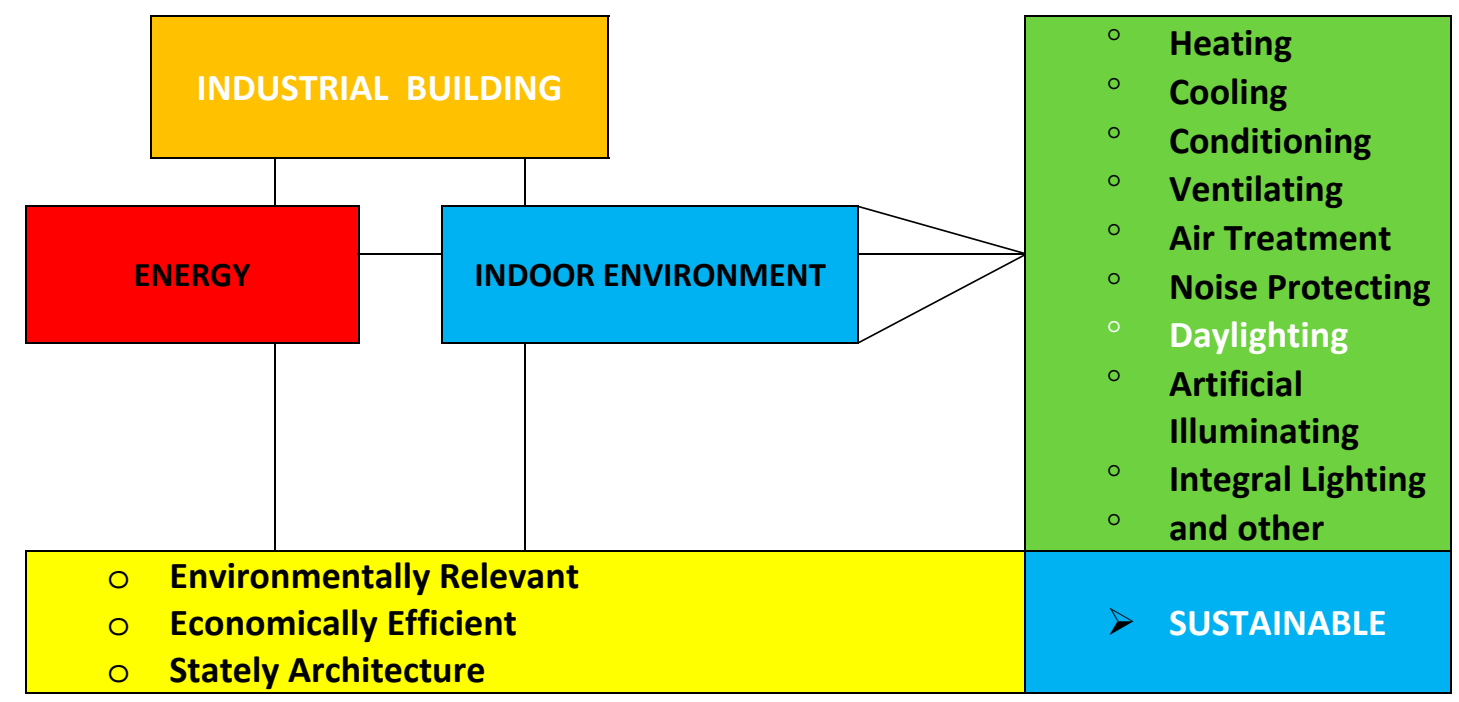

Figure 1. The design of industrial buildings and the role of daylight for the indoor environment and the sustainability requirements.

\subsection{Methodology}

In this article, we take into account the daytime lighting in an industrial factory (a textile factory) outside the city where one hall is above the other (one interior is above the other and there is no shading). The production halls are referred to as A, B, C, D, and so on. We are only interested in one part of the indoor environment-daylighting. It is not possible to meet the daylight requirement for visibility at remote locations with unilateral daytime lighting (on only one side), as shown in Reference [64], where the hall is marked as " $E$ ". The case study in this document points out how there is illumination from two parties (that is, bilaterally) in the " $F$ " and " $G$ " halls.

If we cannot meet the requirements for daylight there must be a combination of daylight and artificial lighting; for example, integral or integrated lighting. The task is to determine the methodology 
for determining the minimum that is required Daylight Factor $(D F)$ for integral lighting, as prescribed by the Czech Technical Standards (CSN). The research was carried out in textile halls in a town located in the eastern part of Slovakia. In this work, we present two knitting factories of the textile industry, which have different window locations. The predominant role of this research is to analyze the impact of window placement on the daylight industrial hall lighting with regard to integrated dynamic simulations and real in situ measurement methods. The on-going view offers an analysis of the daylight conditions that also use measurements in situ and calculation by simulation, leading to the design of windows and the optimization of sustainability monitoring.

This work is a continuation of the comprehensive research of the quality of the internal working environments (internal microenvironments) of industrial buildings.

\subsection{Daylighting According to Czech (CSN) and Slovak (STN) Standards}

In the recent past, a number of technical lighting standards that deal with natural daylight and artificial illumination have changed. The associated lighting is addressed in many standards as part of artificial lighting regulations. The Standard for Building Integral Lighting was also valid in the Czech Republic after the revision. The Daylight Factor $(D F)$ is considered and determined for the assessment of the indoor daylight environment. Equation (1) can be used to calculate this in a cloudy sky with a uniform cloud.

$$
D F=\frac{\text { Internal illuminance }}{\text { External illuminance }} \times 100 \%
$$

Prescription of the $D F$ according to the Slovak standards is shown in Figure 2. The rule for the minimum and average daily $D F$ factor for all seven categories of technical light recognition (see Table 1), according to the Slovak and Czech national standards, can be seen in Figure 2.

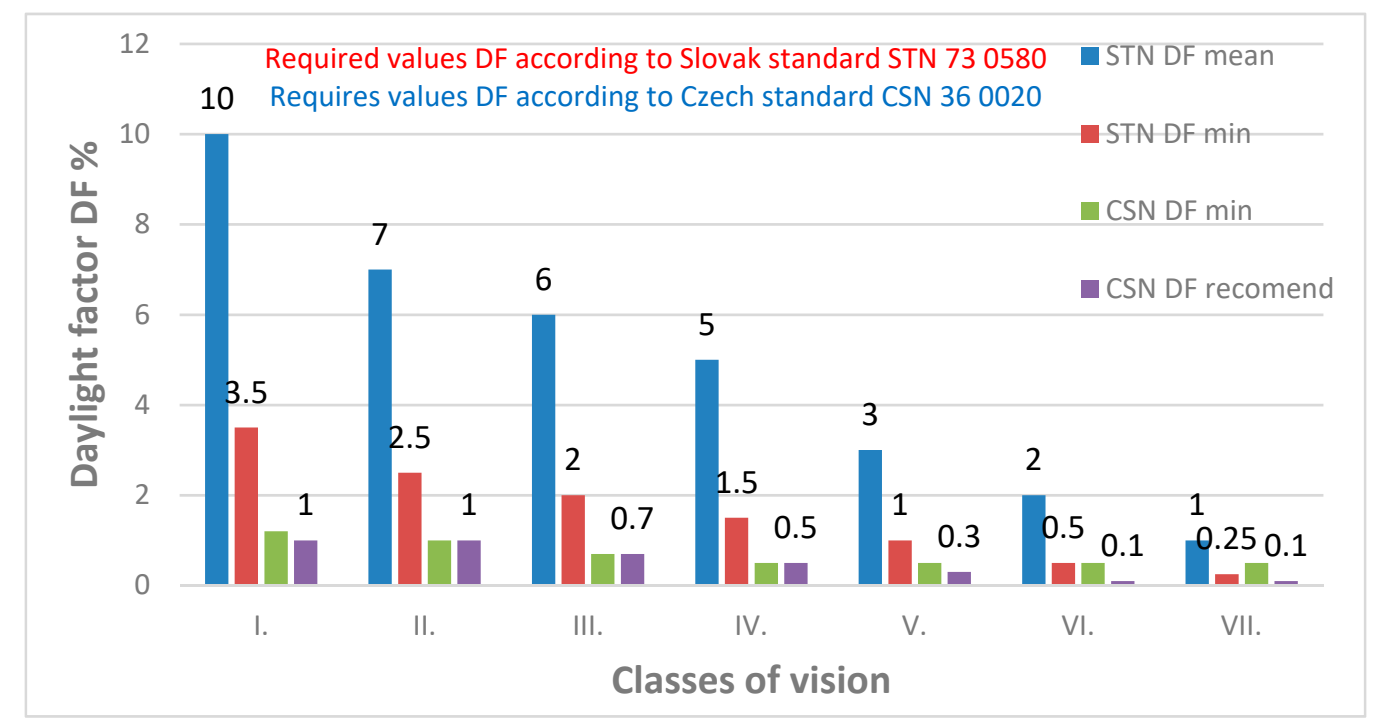

Figure 2. The comparison of the Daylight Factor $(D F)$ prescription according to Czech standard CSN 360020 (Integral lighting) [67] and Slovak standard STN 730580 (Daylighting) [68].

The classification of the internal daylighting indoor-environment, according to Slovak and Czech technical standards, is based on the work, its complexity, and the basic requirements that are placed on the complexity of the visual activity.

Artificial lighting is determined with EN 12464-1 2011 "Light and lighting-Lighting of workplaces, Part 1 Indoor work places" for "night time conditions" only Reference [69]. Namely, the corresponding light levels from the artificial lighting system are calculated without the influence 
of daylight. Thus, only the combination of daylight and artificial light should be with the use of photosensors. However, this is not the subject of our research.

In Czech standards of "Integral lighting in buildings" [67], interiors are classified into seven groups according to the intensity of the visual activities performed inside a building. This is similar to the Slovak standards [68]. The values of the $D F$ are grouped into seven categories representing human eye recognition for visual detail tasks. The main starting point for determining the requirements for integral lighting is the classification of the visual activities that were performed in a building, according to References [67,68] (Figure 2).

Table 1. The classification of human eye recognition of visual detail tasks according to the Slovak national standard STN 730580 [68].

\begin{tabular}{ll}
\hline $\begin{array}{l}\text { Human Eye } \\
\text { Recognition Category }\end{array}$ & \multicolumn{1}{c}{ Visual Detail Tasks } \\
\hline I. Extreme accuracy & $\begin{array}{l}\text { The most accurate visual work with limited use of magnification, with the } \\
\text { requirement to eliminate errors in definition, stringent control }\end{array}$ \\
\hline II. High accuracy & $\begin{array}{l}\text { Very precise production and control activities, high-precision drawing, hand } \\
\text { engraving with very small detailing, fine artwork }\end{array}$ \\
\hline III. Precise operation & $\begin{array}{l}\text { Precision manufacturing and inspection, regular drawing, technical drawing, } \\
\text { laboratory, labour-intensive investigations, fine sewing, embroidery }\end{array}$ \\
\hline IV. Medium accuracy & $\begin{array}{l}\text { Medium precision manufacturing and inspection, reading, writing (by hand and } \\
\text { machine), routine laboratory work, examinations, treatments, using machines, } \\
\text { thicker sewing, knitting, laundry, cooking class, reading room, teaching cabinet, } \\
\text { kitchen, doctor's surgery, office, meeting room, conference room }\end{array}$ \\
\hline V. Low accuracy & $\begin{array}{l}\text { Approximate works, manipulating objects and materials, food consumption and } \\
\text { service, leisure activities, physical education, dining room, living room, lounge, } \\
\text { hall, gymnasium, swimming pool, storage room, waiting room }\end{array}$ \\
\hline VI. Very rough work & $\begin{array}{l}\text { Maintenance cleaning, showering and washing, changing, walking on public } \\
\text { roads open to the public, cloakroom, toilets, corridors }\end{array}$ \\
\hline VII. $\quad$ Only spatial orientation & Walking, material transport, storage of raw material, supervision \\
\hline
\end{tabular}

The same classification applies to the daily STN standards and the CSN integral lighting. The same applies to the relative observation distance. The difference is in the prescribed minimum $D F$ factors (see Figure 2), as well as differences in the permitted luminance.

Problems that are related to industrial buildings have not been thoroughly reviewed until such details as another type of buildings. The criteria for residential and civil non-manufacture buildings do not apply to industrial buildings. Therefore, it is necessary to make certain changes in the methods and approaches to assessing the design of buildings in the industrial sectors.

\subsection{Daylighting According to European Standards}

In the draft of the European standards, the rules are slightly different from national standards. Other factors are taken into account here. This standard evaluates permanently inhabited areas, classifies buildings' premises according to function and work activities, and defines areas with daylighting requirements. The daylight assessment features are applied mainly to industrial areas, offices, civic areas, schools, health-related buildings, business and apartment buildings, and prisons and care homes. The daylight availability is determined by the median of horizontal diffuse illumination at location $\mathrm{E}_{\mathrm{med}}$. Daylight is intended to provide levels of natural light that are higher than the critical visual daylight lighting level of 300 lx. The daily lighting requirements should be adequate, with an acceptable minimum of 100 lux. The target factor $\mathrm{D}_{\mathrm{T}}$ is the daily lighting factor to be achieved in a certain portion of an area in order to meet the daylighting criterion. On the working plane, the illumination level is $300 \mathrm{~lx}$. The daylighting factor $\mathrm{D}_{\mathrm{TM}}$ is the minimum target daylight factor. This is the minimum $D F$ value in a specific location that corresponds to the illuminance level of 
100 lx. Basic daylighting requirements, according to the draft of the European standards [70], can be seen in Tables 2-4:

Table 2. The maximum permissible brightness (luminance) of the subject observed and the brightness of the illuminating opening positioned $60^{\circ}$ from the normal viewing direction according to European Union (EU) standards.

\begin{tabular}{cc}
$\begin{array}{c}\text { Class of } \\
\text { Visual Activities }\end{array}$ & $\begin{array}{c}\text { The Ratio of the Luminance of the Observed Object to the } \\
\text { Luminance of the Illuminating Opening (Windows) }\end{array}$ \\
\hline I, II, III & $1: 40$ \\
IV & $1: 100$ \\
V, VI, VII & not intended \\
\hline
\end{tabular}

Note: The usual direction of view is a view of the subject of work or other view related to the activity and the relaxation view in the horizontal direction.

Table 3. Recommendation of daylight provision by daylight openings in vertical and inclined surfaces [70].

\begin{tabular}{|c|c|c|c|c|c|}
\hline $\begin{array}{l}\text { Level of Recommendation } \\
\text { for Vertical and Inclined } \\
\text { Daylight Opening }\end{array}$ & $\begin{array}{c}\text { Target } \\
\text { Illuminance } \\
\mathrm{E}_{\mathrm{T}}(\mathbf{l x})\end{array}$ & $\begin{array}{l}\text { Fraction of Space } \\
\text { for the Target } \\
\text { Level } F_{\text {plane, }}(\%)\end{array}$ & $\begin{array}{l}\text { Minimum Target } \\
\text { Illuminance } \\
\mathrm{E}_{\mathrm{TM}}(\mathbf{l x})\end{array}$ & $\begin{array}{c}\text { Fraction of Space } \\
\text { for Min Target Level } \\
\text { F }_{\text {plane, }}(\%)\end{array}$ & $\begin{array}{c}\text { Fraction of } \\
\text { Daylight Hours } \\
\text { F }_{\text {timer }}(\%)\end{array}$ \\
\hline Minimum & 300 & $50 \%$ & 100 & $95 \%$ & $50 \%$ \\
\hline Medium & 500 & $50 \%$ & 300 & $95 \%$ & $50 \%$ \\
\hline High & 750 & $50 \%$ & 500 & $95 \%$ & $50 \%$ \\
\hline
\end{tabular}

NOTE: Table 3 in Reference [70] states that the target daylight factor $\left(D_{T}\right)$ and the minimum target daylight factor $\left(D_{T M}\right)$ corresponds to the target illuminance level and the minimum target illuminance, respectively, for the European Committee for Standardization (CEN) capital cities.

Table 4. Assessment of the view outwards from a given position [70].

\begin{tabular}{cccc}
\hline & \multicolumn{2}{c}{ Parameter (a) } \\
\hline $\begin{array}{c}\text { Level of } \\
\text { recommendation } \\
\text { for view-out }\end{array}$ & $\begin{array}{c}\text { Horizontal } \\
\text { sight angle }\end{array}$ & $\begin{array}{c}\text { Outside distance } \\
\text { of the view }\end{array}$ & $\begin{array}{c}\text { Number of layers to be seen from at least } \\
75 \% \text { of the utilized Area: -Sky-Landscape } \\
\text { (Urban and/or Nature)-Ground }\end{array}$ \\
\hline Minimum & $\geq 14^{\circ}$ & $\geq 6.0 \mathrm{~m}$ & At least the landscape layer is included \\
\hline Medium & $\geq 28^{\circ}$ & $\geq 20.0 \mathrm{~m}$ & $\begin{array}{c}\text { Landscape layer and one additional } \\
\text { layer are included in the same view opening }\end{array}$ \\
\hline High & $\geq 54^{\circ}$ & $\geq 50.0 \mathrm{~m}$ & All layers are included in the same \\
view opening
\end{tabular}

(a) For a space with room depth of more than $4 \mathrm{~m}$, it is recommended that the respective sum of the view opening(s) dimensions is at least $1.0 \mathrm{~m} \times 1.25 \mathrm{~m}$ (width $\times$ height).

The draft of the European Union (EU) standards shows the values of the $D F$ for daylight openings exceeding an illuminance level of $100,300,500$, or $750 \mathrm{~lx}$ for a fraction of the daylight hours $\mathrm{F}_{\text {time }}(\%)=50 \%$ for 33 capitals of Committee for Standardization (CEN) national members.

The values of the $D F$ only for horizontal daylight openings with diffusing material exceeds an illuminance level of 100, 300, 500 or $750 \mathrm{~lx}$ for a fraction of daylight hours $\mathrm{F}_{\text {time }}(\%)=50 \%$ for 33 capital cities of CEN national members [70,71].

\section{A Case Study: Textile Factory}

The subject in this case study is a textile factory that is located in the eastern part of the Slovak Republic in which two knitting halls were observed. It is a three-storey steel-skeleton building that is surrounded by a lightweight cladding and connected windows (window strip).

There are a lot of spaces in this factory called A, B, C, D, and so on. In Reference [64], we considered hall $\mathrm{E}$ and in this paper, we evaluate hall $\mathrm{F}$ and hall $\mathrm{G}$, which are illuminated by daylight from two sides. 
Figure 3 shows the view of the building from the outside and the internal view as a result of daylight simulation with the Radiance simulation program.

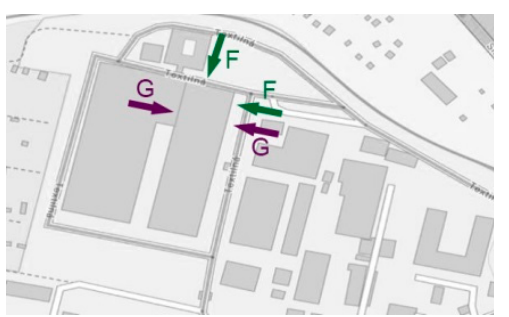

(a)

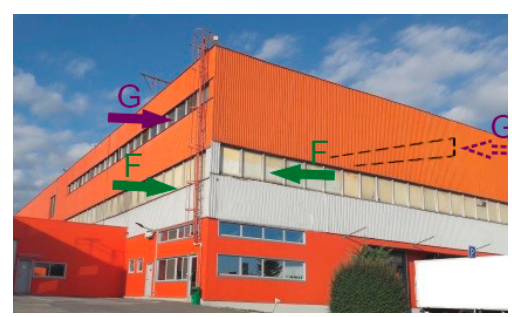

(b)

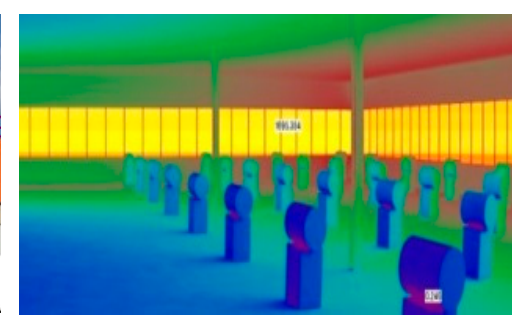

(c)

Figure 3. The situation of a textile factory placement, lighting simulation results near windows in the double-side window day illumination. (a) Situation of case study; (b) Bilateral daylight system; and (c) Luminance Internal view.

In this article, we want to showcase studies of similar industrial factories that are illuminated by a double-sided daylight system (a strip of windows):

Windows are next to each other in the neighbouring perimeter walls (hall F-see Figure 4).

Windows are in perimeter walls against each other (hall G—see Figure 4).

In these halls was realised:

(1) measurement of daylight value,

(2) determination of the marginal conditions for the calculation of the $D F$,

(3) calculation and simulation of the daylight situations using the simulation program,

(4) confrontation of measured and calculated DF values, and

(5) the derived simplified formula for the window design depending on the floor area to determine the minimum $D F$ (for integral lighting as a basis).
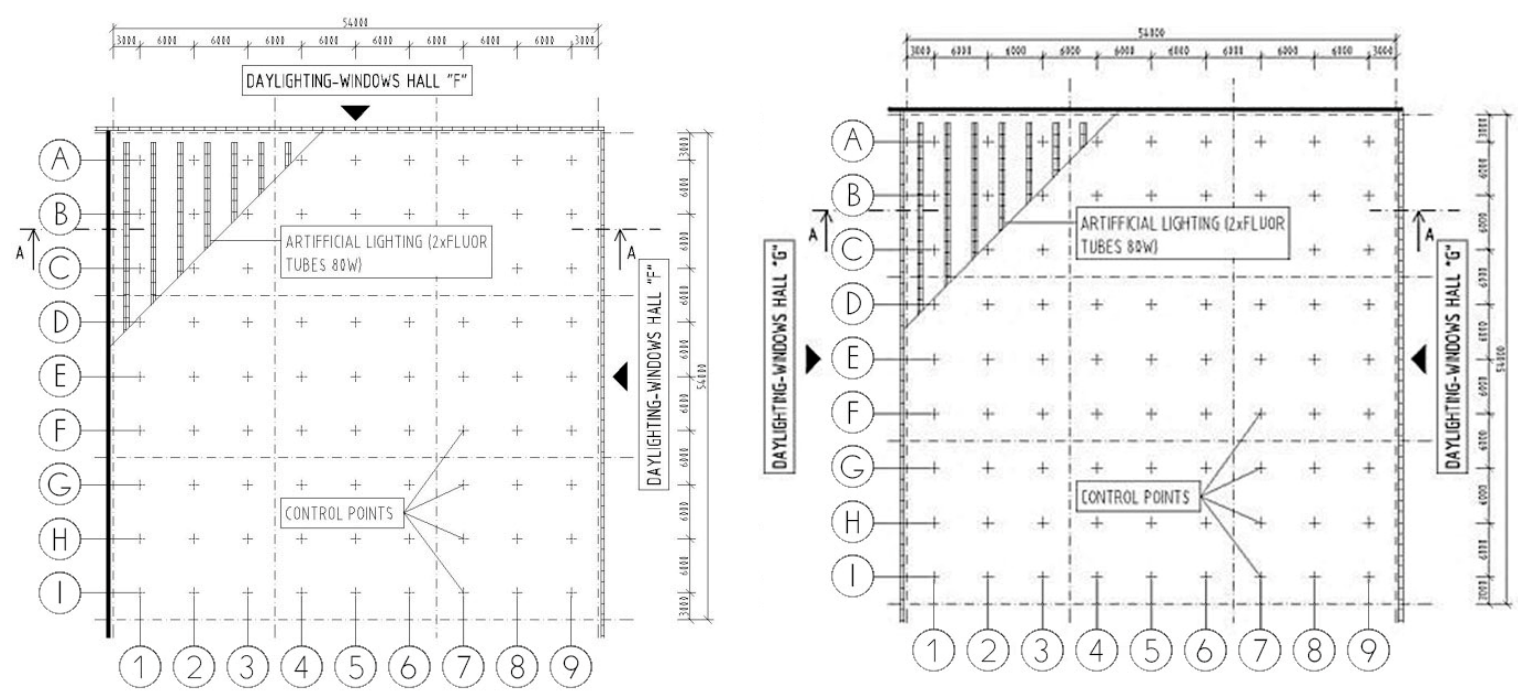

Figure 4. The floorplan of halls F and G.

\subsection{Daylight Measurements}

Daylight measurements were performed according to Slovak standard "Measurement of daylighting". The measuring instruments were borrowed from the STU Faculty of Civil Engineering in Bratislava. The instruments were two "Hagner EC 1 type" lux meters with the following production 
numbers: 5532 and 5531, a "Hagner Universal Photometer type S2, S22065" with an accuracy of $5 \%$, and the "Hagner Reference calibration sample" with a factor value and a reflection of 0.966 . When using a daylight system (according to Slovak valid standard STN 73 0580-1), the minimum standard value $D F_{\min }=1.5-2 \%$, the average normalized value $D F_{\text {average }}=5-6 \%$, and the uniformity of the illumination is more than $0.2-0.3$ for a given visual task. According to standard measurements of daylighting, the change in the luminance of the sky at a given height to sky luminance in zenite at $15^{\circ}$ is $0.3-0.6$ and $0.7-0.85$ is acceptable at $45^{\circ}$ (see Figure 5). The measured sky conditions rating gradations of brightness (sky luminance) in the two considered days in December and January can be seen in Figure 5. In Figure 5, $x$ refers to the elevation angle and $y$ to the Le/Lz ratio.

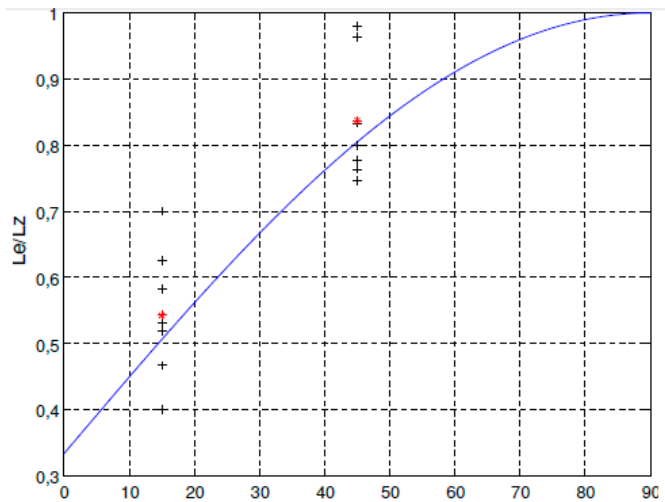

(a)

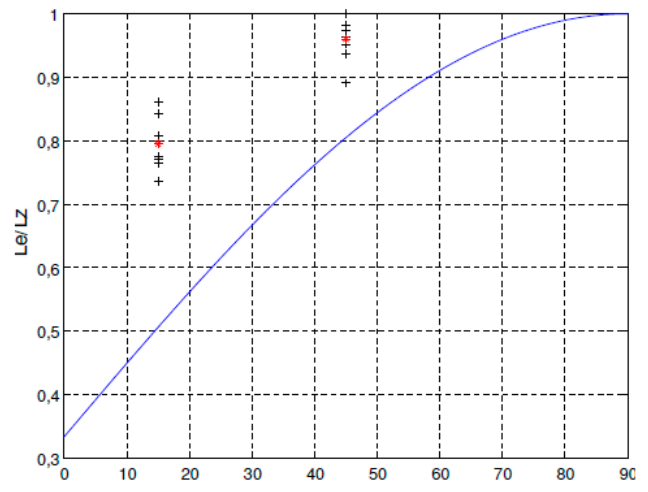

(c)

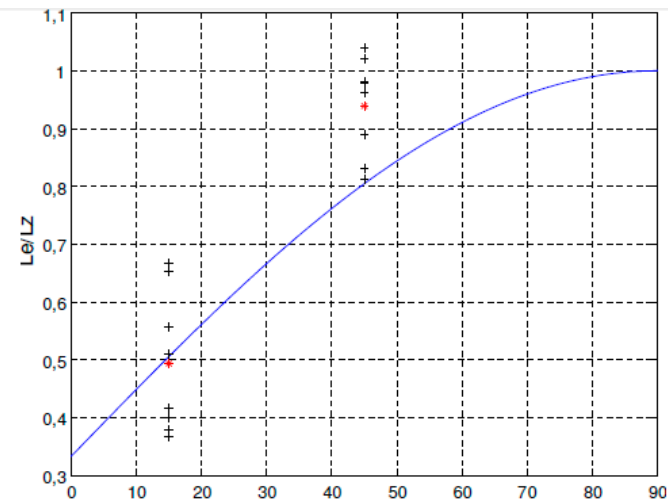

(b)

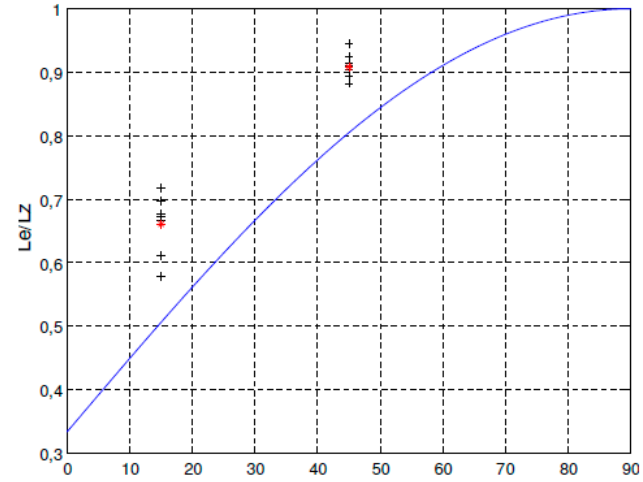

(d)

Figure 5. The measured sky conditions rating gradations of sky luminance, $x$-refers to the elevation angle, $y$-refers to the Le/Lz ratio, Le refers to the external sky luminance, and Lz refers to the sky luminance at an angle of $\mathrm{Z} 15^{\circ}$ and $45^{\circ}$. First day (a) the beginning; and (b) the end of the measurement $x$ - elevation angle, $y$ - Le/Lz ratio. Second day (c) the beginning; and (d) the end of the measurement $x$-elevation angle, $y-$ Le/Lz ratio.

Daylight measurements were performed on two different days, when the artificial lighting system was switched off. Control points during the measurement were from the floor at $850 \mathrm{~mm}$, because the need for visual power is at a given height. Measurements were performed at 81 control points simultaneously with two lux meters.

If the device is unable to take a measurement at the specified points, the value is measured at approximately $30-50 \mathrm{~cm}$ outside the point. One light measuring device measured illumination at a designated location inside the hall. The second light measurement was external, on a horizontal surface (on the roof). Daylight measurements were performed on the first day twice and the other days three times (see Figure 5). At the level of the roof structure, the measurement of the outdoor horizontal illumination and the external illuminance (see Equation (1)) was measured on a plane that was not shaded. 
On the selected days, the value of the outside light in a cloudy sky ranged from 4000 lx-8000 lx on the first day and 5000 lx-8000 lx on the second day, when the light was measured in the direction of the cardinal. The measurements of the luminance distribution in the clouds at the measuring site were performed on both days, at the beginning and at the end of the measurement. The comparison of the measured values with the normalized luminance distribution of an evenly cloudy sky on the dark terrain is shown in Figure 5. The final $D F$ values measured at the control points are shown in Figure 6 .

From the graphs in Figure 5, it can be seen that the values of the sky luminance at the specified altitude before and after the measurement were done are almost within the allowed range. The results of the measurement values can be seen in Table 5 .

Table 5. The measured sky conditions rating gradations of sky luminance.

\begin{tabular}{|c|c|c|c|c|c|}
\hline \multicolumn{6}{|c|}{ First Day } \\
\hline \multicolumn{3}{|c|}{ (a) at the beginning of measurements } & \multicolumn{3}{|c|}{ (b) at the end of measurements } \\
\hline Z & $\mathrm{Le} / \mathrm{Lz}$ & Average value & Z & $\mathrm{Le} / \mathrm{Lz}$ & Average value \\
\hline $15^{\circ}$ & $0.4-0.7$ & 0.55 & $15^{\circ}$ & $0.35-0.68$ & 0.50 \\
\hline $45^{\circ}$ & $0.75-0.85$ & 0.85 & $45^{\circ}$ & $0.80-1.05$ & 0.92 \\
\hline \multicolumn{6}{|c|}{ Second Day } \\
\hline \multicolumn{3}{|c|}{ (a) at the beginning of measurements } & \multicolumn{3}{|c|}{ (b) at the end of measurements } \\
\hline $\mathrm{Z}$ & $\mathrm{Le} / \mathrm{Lz}$ & Average value & Z & $\mathrm{Le} / \mathrm{Lz}$ & Average value \\
\hline $15^{\circ}$ & $0.774-0.86$ & 0.80 & $15^{\circ}$ & $0.61-0.72$ & 0.68 \\
\hline $45^{\circ}$ & $0.89-1.0$ & 0.95 & $45^{\circ}$ & $0.88-0.92$ & 0.90 \\
\hline
\end{tabular}

It was measured in nine rows (direction E-W) labelled A-I at distances of 3, 9, 15, 21, 27, 33, 39, 45 , and $51 \mathrm{~m}$ from the edge of the peripheral wall. In the longitudinal direction of the hall, it was also measured in nine rows marked $1-9$ at distances of $3,9,15,21,27,33,39,45$, and $51 \mathrm{~m}$ from the peripheral wall edge (Figure 7).

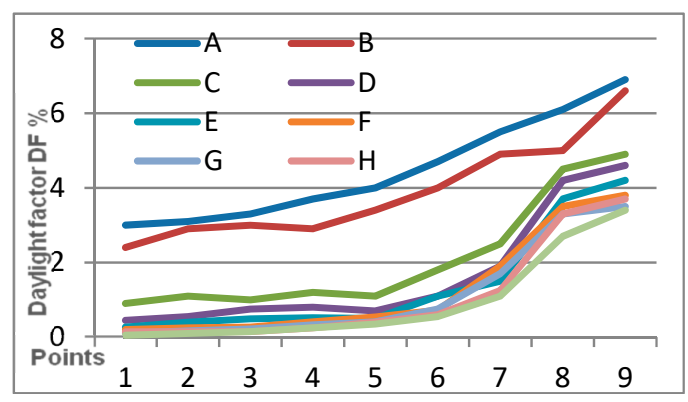

(a)

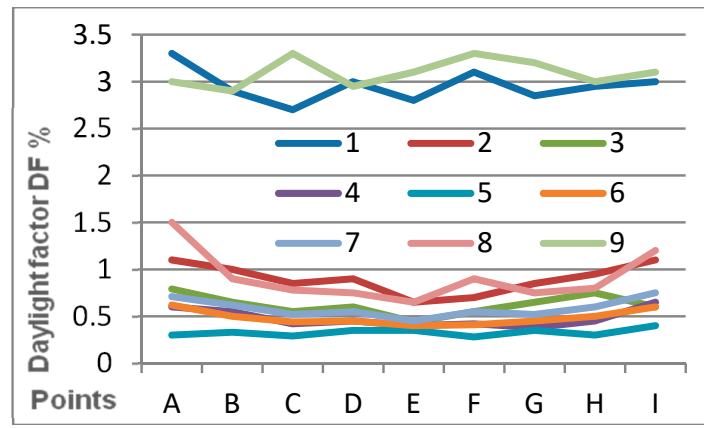

(c)

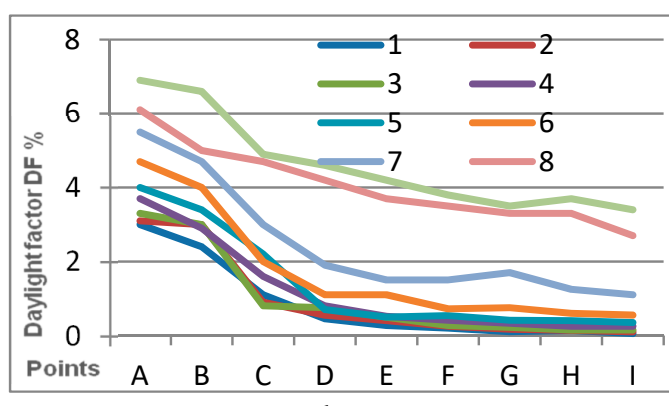

(b)

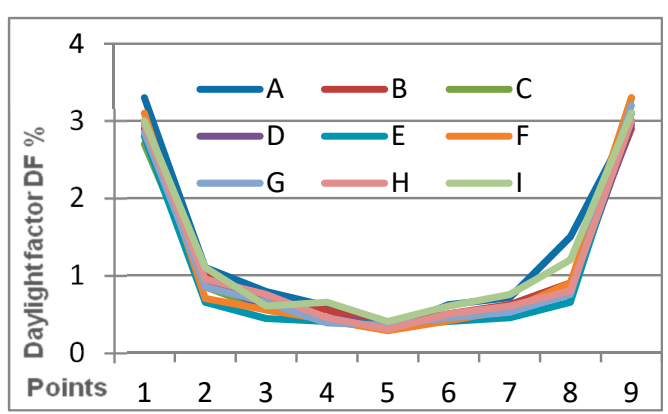

(d)

Figure 6. The measured DF values at the control points in halls F and G in sections I-I, II-II, III-III and IV-IV. (a) Hall "F" section I-I; (b) Hall "F" section I-I; (c) Hall “G" section III-III; and (d) Hall "G" section IV-IV. 
Daylight measurements were made in December and January when the sky was cloudy. The DF values shown in Figure 6 are calculated from the measurement results as the average value of the five measurements. From these data, the $D F$ evaluation parameters that are shown in Figure 7 were calculated. The spatial distribution of $D F$, the curves of the same brightness curves, and the $D F$ curve decreases with respect to the depth of the space that is being considered. This is similar in Figures 8-10.

The light reflection factor was determined according to the Slovak standards. Luminance was located according to the wall, ceiling, floor, and interior. From the measured luminance values of the individual surfaces and the known reflection factor of the calibration sample, the resulting reflection factor of the measured surfaces was calculated. The values of the calculated reflection factors were used as inputs for assigning the properties of the material surfaces in the hall.
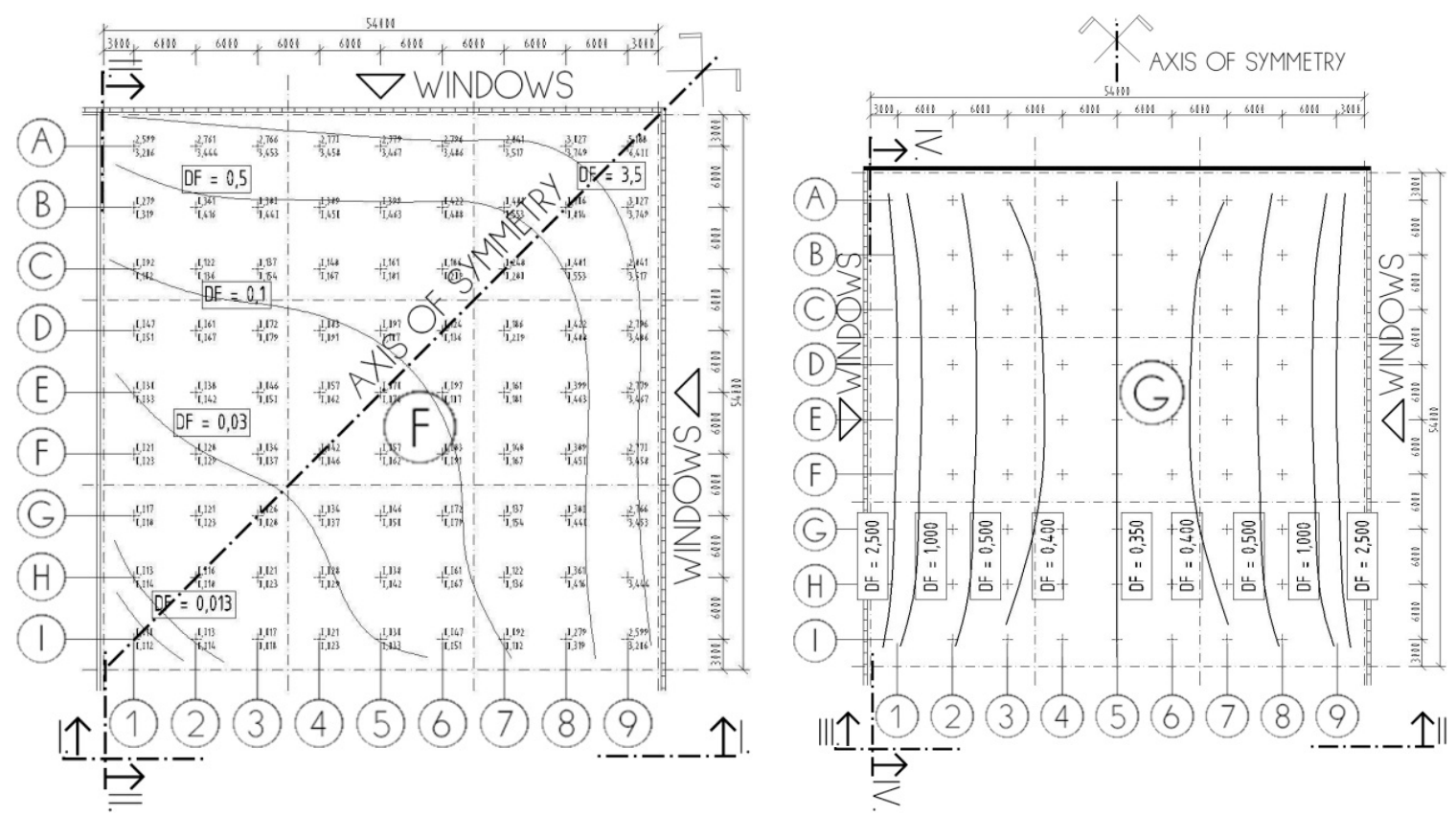

Figure 7. Schematic pictures of the predicted lines with the same DF in halls F and G at 81 control points (from A1-I9), indicating sections I-I, II-II, III-III, and IV-IV for displaying the measured values.

\subsection{Daylight Calculations}

The boundary conditions for calculations have been observed in the measurement of daylighting. The following conditions for calculation were considered.

The external illuminance is considered to be 5000 lx; (in the draft EU standards it is considered different for every capital city of the $33 \mathrm{EU}$ members. For Bratislava (Slovakia) it is 16,300 lx). The height of the interior space of hall is $5100 \mathrm{~mm}$. The parapet is at a height of $1200 \mathrm{~mm}$. The dimensions of the windows - the height of the window strip is $2400 \mathrm{~mm}$ and the wall thickness varied between 100-300 mm.

The light loss coefficients, normal light transmittance $\tau_{\text {glazing }}=\tau_{1}=0.92$. The influence of the frame on light transmittance of windows $\tau_{2}=0.74$. The influence of glass cleanliness $\tau_{3}=0.80$ and the influence of interior and shading elements $\tau_{4}=1.0$.

The coefficients of reflections $(\rho)$ of the light of individual surfaces: white ceiling $\rho=0.75$, glass areas $\rho=0.10$, walls $\rho=0.70$, external terrane $\rho=0.15$ (no snow), light green mop board $\rho=0.65$, light brown floor $\rho=0.50$, and façade $\rho=0.45$. For plants located outside the city, where one hall is above the other, there is no shading. $Z=0$. 
The DF values in hall F (double-sided daylight system of windows next to each other) and hall $G$ (double-sided daylight system of opposite windows) are measured and computed. The halls reduce the DF due to the depth of the space.

The results of the DF and lighting calculated in the F and G halls and the luminance $\left(\mathrm{cd} / \mathrm{m}^{2}\right)$ in halls $F$ and $G$, calculated without a space device can be seen in Figure 8.

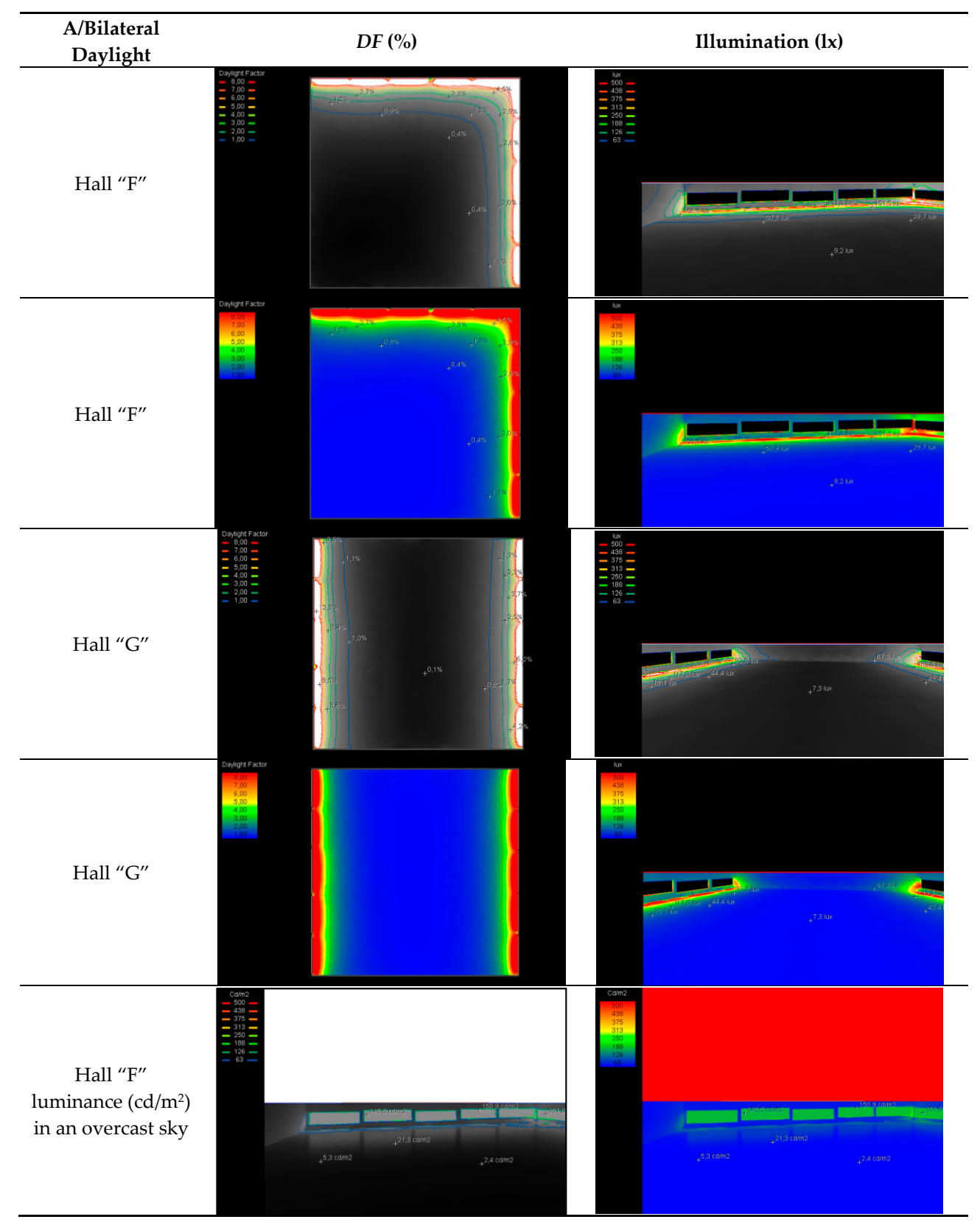

Figure 8. Cont. 


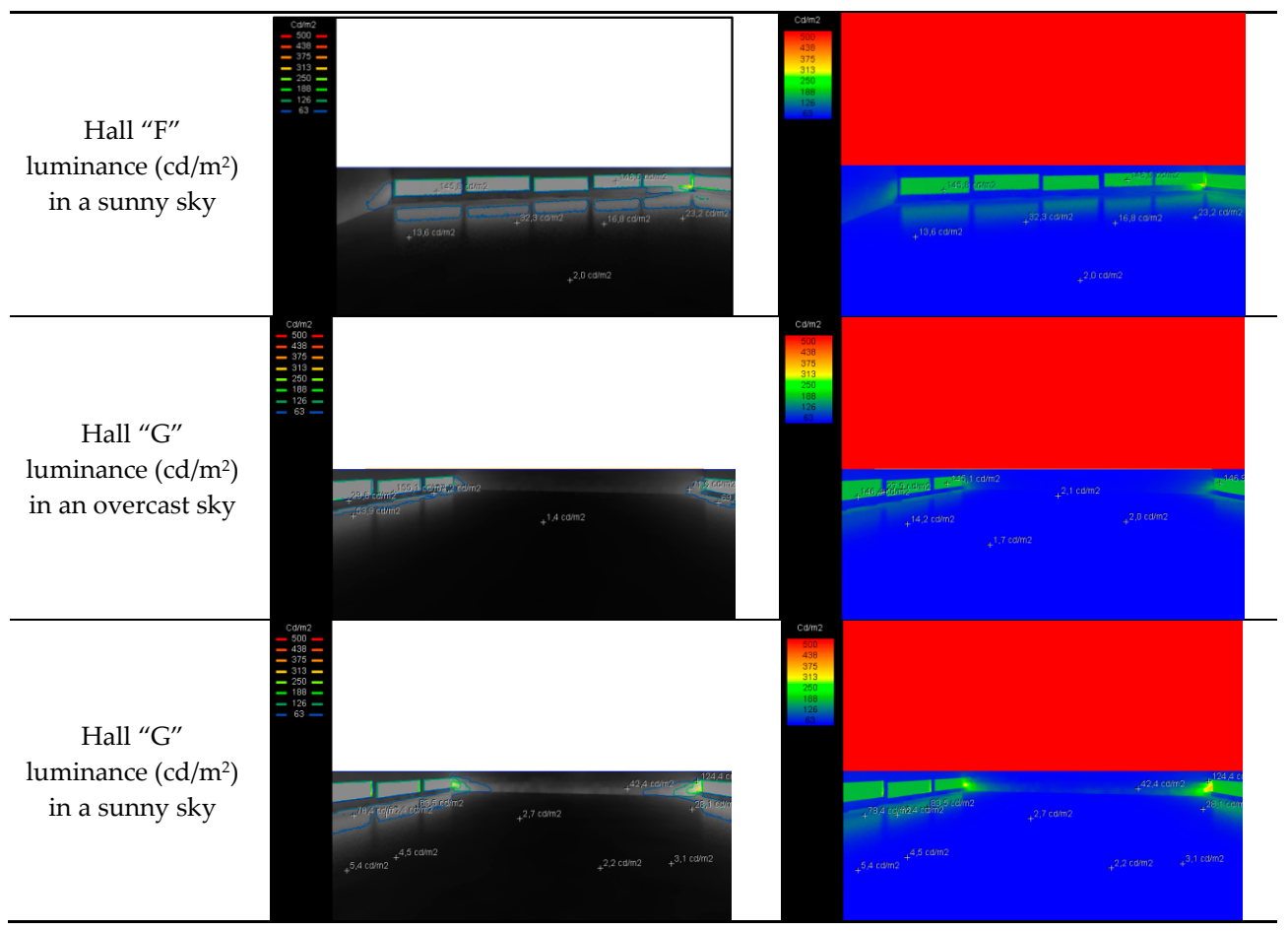

Figure 8. Results of the daylight factor DF (\%), illumination I (lx), and luminance (cd/m2) in halls F and $G$ calculated in an unfurnished interior.

In hall E, the daytime lighting was provided on one side only (see Reference [64]). The results are similar to those in halls $F$ and $G$, except that the symmetry is different. In hall $F$, the symmetry axis is diagonal across points A9-I1 (Figure 7). In hall G, it is in the centre through points A5, B5, C5, and so on to I5. In hall $\mathrm{F}$, there were no duplications of results at any of the points, despite the fact that the lighting was from two sides. In hall $\mathrm{G}$, the daylight factor can be determined by the superposition of values. It is the sum of the highest value near the windows and the lowest value at the extreme point. At other points, the results are mirrored (Figure 7). When it comes to simulation programs, this is different. The results depend on the program that is used and the exact specification of the input data. Some programs also take into account the interior and the production process. In industrial buildings, it is quite difficult to simulate a situation that would correspond to reality. We tried to especially simulate the visual perception of the interior, the observed detail, and the view of the windows. The results using simulation programs for the furnished interior can be seen in Figure 9.

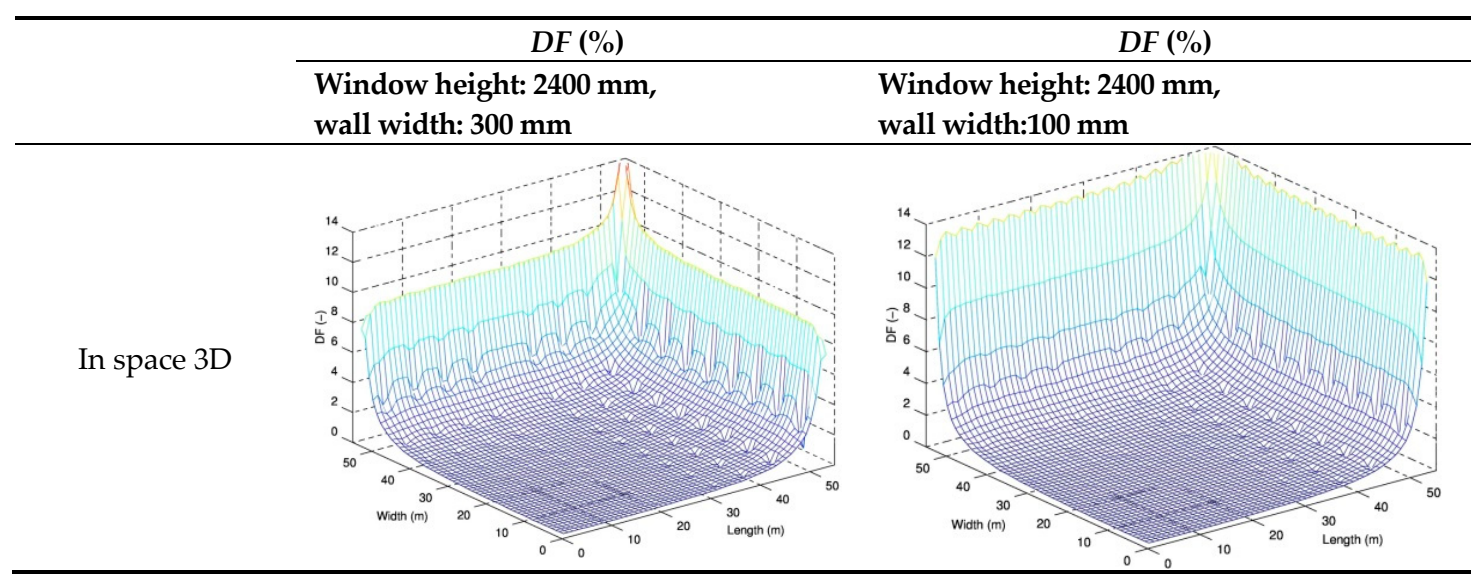

Figure 9. Cont. 


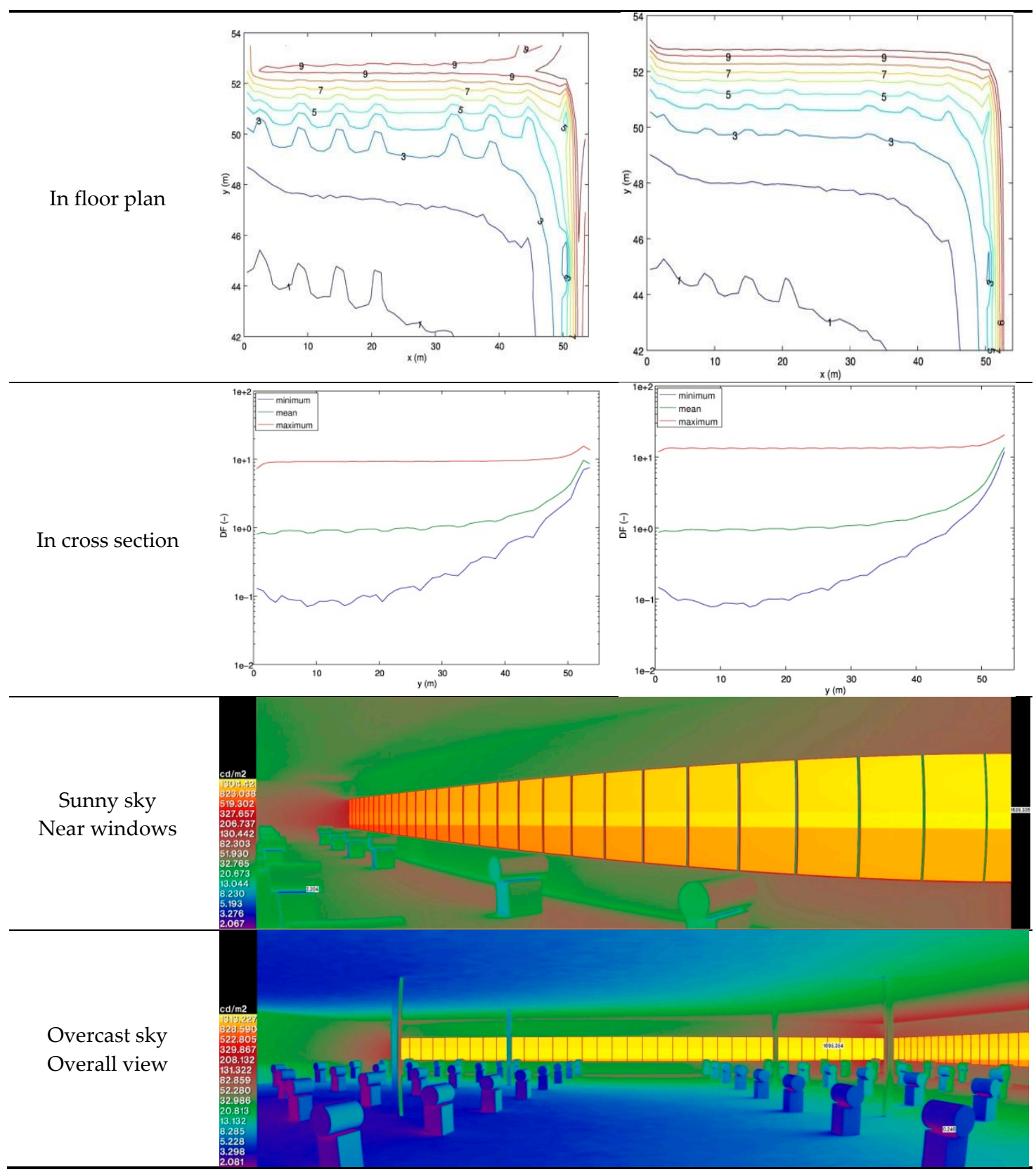

Figure 9. The results of the daylight factor DF (\%) and illumination I (lx) in hall $\mathrm{F}$ and results of luminance $(\mathrm{cd} / \mathrm{m} 2)$ in hall $\mathrm{F}$ with the hall equipment calculated by the radiance simulation program.

In Figure 10, the level of DF factor in space (3D), in the floor plan (2D), and in the section (1D) for alternative calculations with wall thickness variations of $300 \mathrm{~mm}$ and $100 \mathrm{~mm}$ can be seen. Figure 10 shows the outputs obtained by the same procedure for hall $\mathrm{G}$.

The calculation that tracks the results for hall $\mathrm{G}$ was done with the same simulation programs as for hall F. Hall G has a two-sided illumination system with windows facing each other. Alternatively, the daylight factor DF (\%) for a window height of $2400 \mathrm{~mm}$ and a wall thickness of $300 \mathrm{~mm}$ and $100 \mathrm{~mm}$ can be seen in the 3D space, in the plan view, and in the section plane. The luminosity in the furnished interior is interesting. 


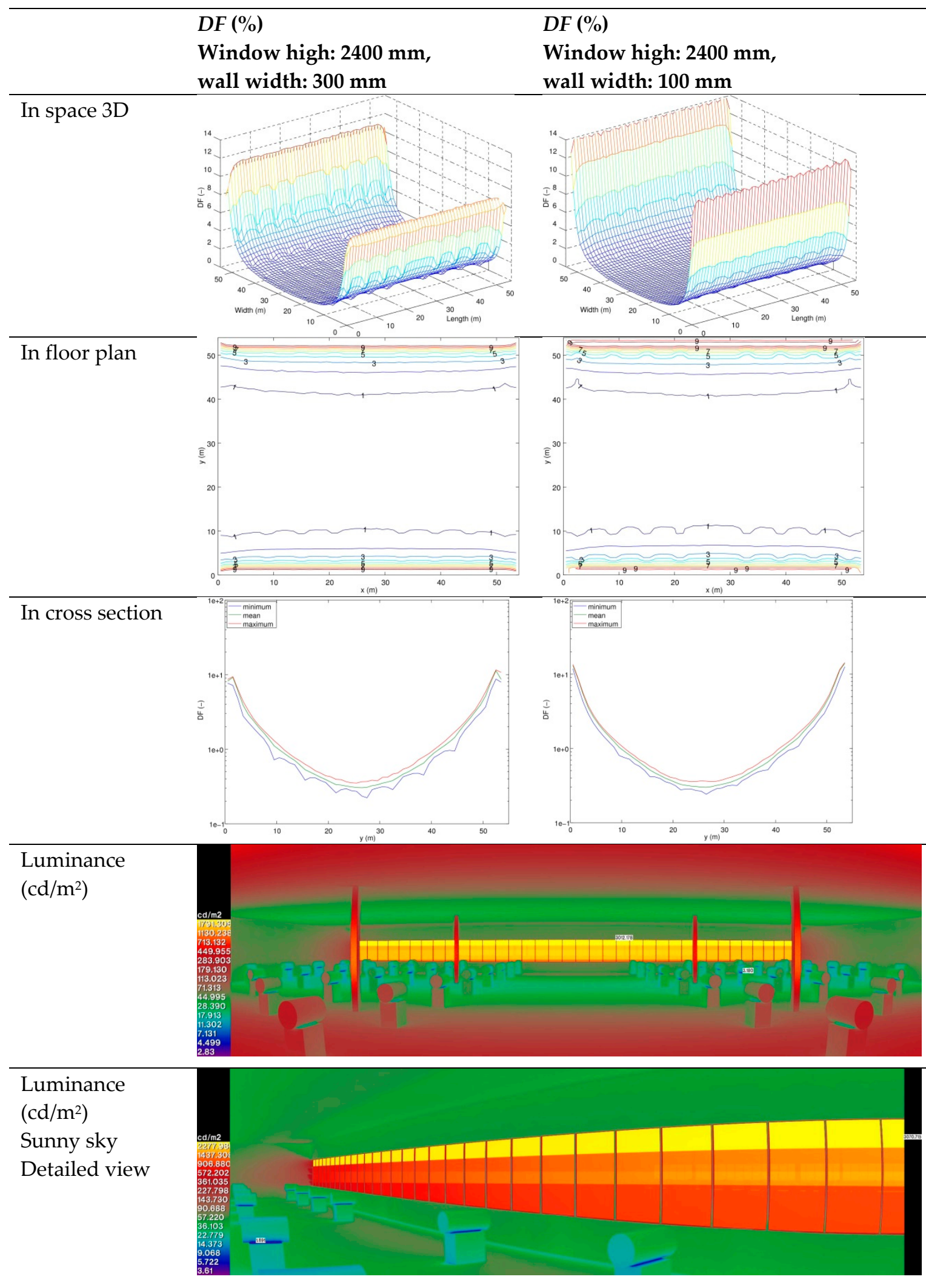

Figure 10. Cont. 


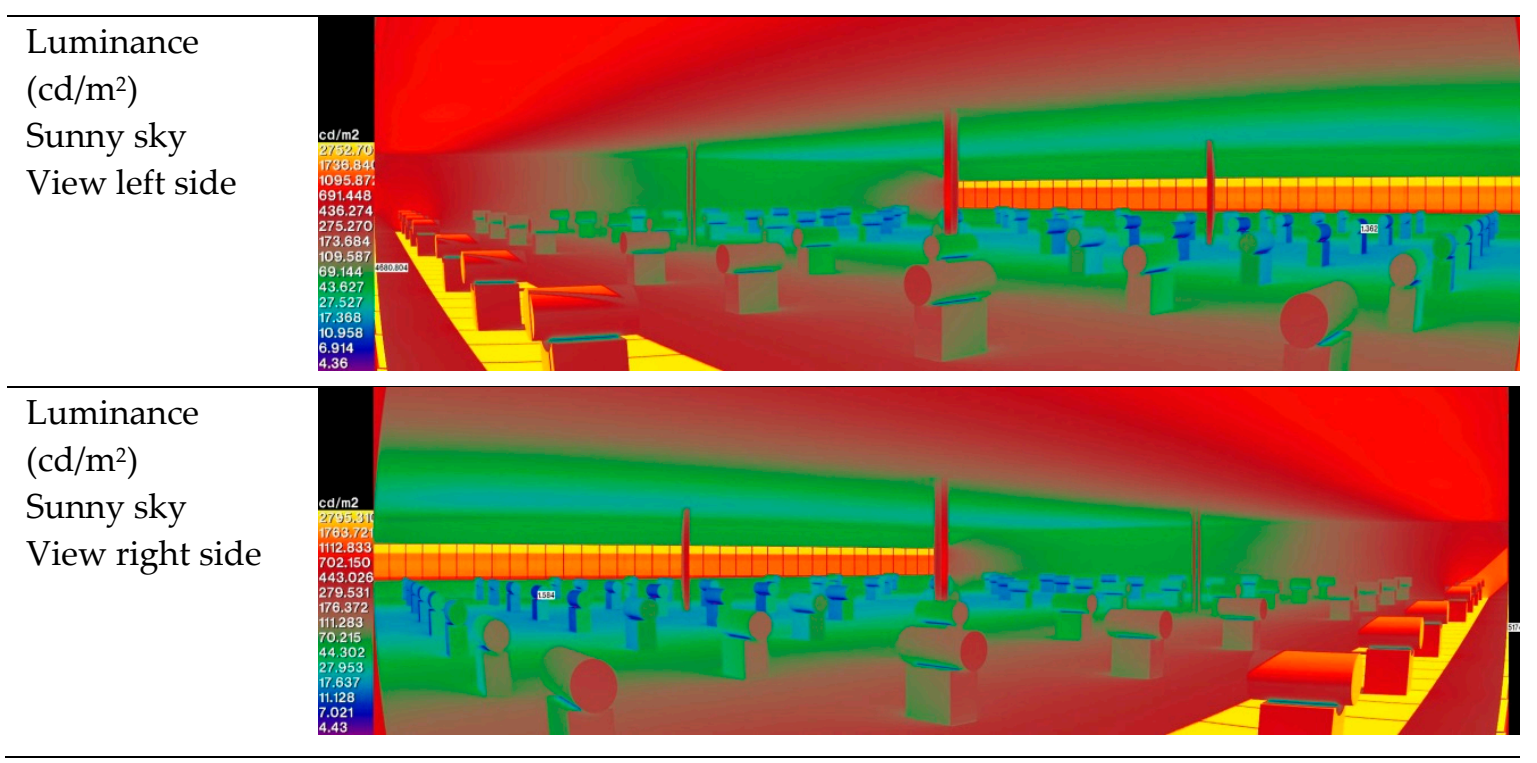

Figure 10. The results of the daylight factor DF (\%) and illumination I (lx) in hall G and the results of the luminance $(\mathrm{cd} / \mathrm{m} 2)$ in hall $\mathrm{G}$ with the hall equipment calculated by the radiance simulation program.

\subsection{Evaluation of the Case Study}

The values of the selection characteristics of a set are calculated at each measurement point. In the creation of the hall model, the marginal conditions were created based on measurements in the hall. Individual measured material constants (factors of reflection of surfaces, pollution factors, and glazing permeability) were considered. In this study, the results of measurement and calculation data for the control points are also presented. By comparing the calculated and measured data, we can conclude that the course is similar. As far as the level of daylight is concerned, there are differences. The $D F$ has three components 1-sky $D F_{s k y}$, 2-reflective inner components $D F_{i}$, and 3-reflective outer components $D F_{e}$ that can be calculated as $D F_{\text {reflected }}$ (see Reference [64]). This is calculated in most of the cases together, and has the value of $D F_{\text {reflected. }}$ Relationships 2-4 can be used for Dw points based on the above analysis. The diameter $D F_{\text {reflected }}$ can be used as the $D F$ factor in the centre of the space considered, where the windows are the same (hall F). The $D F$ measured value (in hall F) is almost twice as high in close proximity to the windows as it is in hall $G$, where the windows are opposite (Figure 7). The lowest DF level is in the outermost positions of the windows (point I1 in hall F and in the symmetry axis of hall G-points A5-I5). The noticeable impact of daylight can be seen at points about $9 \mathrm{~m}$ away from the windows. Then, the level of daylight shifts sharply. The resulting measured value approximates to $D F_{s k y}$. The $D F$ values may be lower due to device shading. This is shown in Figure 8, where the results are obtained using a calculation simulation program.

Changing the level of the reflection component $D F_{\text {reflected }}$ at the distance from the daylight opening Dw is expressed by Equation (2) [64]. The reflected component $D F$ at the distance Dw from windows

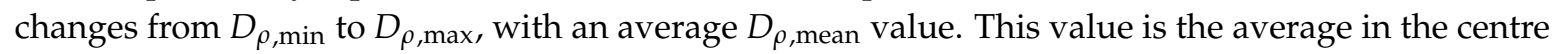
of the space under consideration. The $D F$ can be expressed by Equation (2).

$$
D F=D_{\rho, \text { mean }} K^{\psi}
$$

$k$ and $\psi$ in Equation (2) can be calculated using Equation (3) and Equation(4).

$$
K=\frac{D_{\rho, \text { min }}}{D_{\rho, \text { mean }}}(-)
$$

$D_{\rho, \max }$-Maximum internal reflected daylight factor (\%). 
$D_{\rho, \text { mean }}$-Mean (average) internal reflected daylight factor (\%).

$D_{\rho, \text { min }}$-Minimum internal reflected daylight factor (\%).

$$
\psi=\frac{2 D_{w}-T_{d}}{T_{d}-2}(-)
$$

$D_{w}$-Distance from daylight opening (m).

$T_{d}$-Distance of the outermost point from the windows in the space considered.

The resulting $D F$ also influences the peripheral wall structures. Figures 6 and 7 have documented the results of the $D F$ and illumination for alternative wall thicknesses of $300 \mathrm{~mm}$ and $100 \mathrm{~mm}$ in the $3 \mathrm{D}$ space in the plan view and in the section.

The daylight and DF were measured in several production halls. This article shows two case studies. When analyzing the proportion of the glazed area (windows in the vertical plane) to the floor area, this proportion varies from $3-6 \%$ in halls with a large floor area.

Based on this analysis, we can also calculate the $D F$ relationship in this case, which uses the percentage of glazing $P$ :

$$
P=\frac{A_{W}}{A_{F}}(-)
$$

We can express daylight factor as:

$$
D F=\left(2.926 D_{w}{ }^{-2.115}\right) \cdot P^{B}
$$

where

$A_{W}$-Area of the window structures $\left(\mathrm{m}^{2}\right)$.

$A_{F}$-Area of the floor $\left(\mathrm{m}^{2}\right)$.

$B$-can be calculated by:

$$
B=1.287+0.126 D_{w}-6.6 \times 10^{-3} D_{w}{ }^{2}+9.8 \times 10^{-5} D_{w}{ }^{3}
$$

In this study, we reviewed and analysed the effectiveness and adequacy of daylight that forms the basis for the application of integral light. A case study was conducted in two large industrial buildings to get a picture of the state of the environment and the ability to meet the relevant standards. As mentioned in the accompanying lighting application, there is a prescription-a standard in the Czech Republic that prescribes the minimal indoor climate requirements for minimum daylight (Figure 2). Emphasis has therefore been put on the use of daylight to increase the visual comfort of the industrial hall during the day, and thus the possibility of saving energy on artificial light. We have noticed that daylighting in the tested knitting hall of a textile factory does not meet the required conditions throughout the work area. The hall is used during the day, where there are pleated machines that are utilised by the workers. At points and places where the values are lower than the required illumination size, artificial lighting, such as electric lights, is needed to supplement the daylight to reach the desired levels. The overall situation is particularly interesting in terms of visual perception.

The lights that run during the daytime in hall $\mathrm{F}$ are closer to the windows and two times higher than in the hall G. Daily light was measured when artificial light sources were switched off.

\section{Conclusions}

Our task was to evaluate the daylight lighting in selected areas of the textile factory that is located in the east part of Slovakia. After performing preliminary calculations, following in situ measurements, and modelling and calculations using simulation programs, the following can be stated. A common parameter for daylight saving is the $D F$ factor (daylight factor) in many countries. The daylight level 
measurement is relatively complicated because the level of outdoor lighting may change during the day. Finding a suitable day when acceptable conditions are met is difficult. Although the criteria are met and the outdoor lighting is within the allowed range, it may change during the measurement, especially when there are a lot of control points. In our case study, we wanted to show how this task can be done. In the ordinary interior of the residential buildings, it is easier because the space is relatively small. In industrial buildings, the interiors are large in size. Sometimes the production halls are above and the upper daylight (skylights) can only be applied in the floor under the roof. On the lower floors, it is possible to modify the structures or use the light pipe. When using windows only (as is this case), there is a significant drop in the DF.

In this case, the hall was an industrially operating hall that measured $54 \mathrm{~m} \times 54 \mathrm{~m}$ with a height of about $5 \mathrm{~m}$. This type of "hall" can also be compared with large spaces in other buildings (not only industrial). Such spaces are also typical for administrative and other buildings where there is a free arrangement without built-in partitions. In this study, a simple relationship to predict the level of daylight was derived, depending on the area of the windows. This relationship can be used to predict the size of glazed parts in the outer wall in the given areas. Since the daylight-protected windows are inadequate, it is necessary to bring light to other distances in a different way. As we know, daylight is at least physiologically and psychologically necessary. The person inside must feel the connection between the enclosed interior and the exterior. This is sometimes only a visual idea that cannot be mathematically described. Therefore, the need for daylight in the conditions that we described is necessary if the daily factor $D F$ is a low value.

The calculations that we have performed and confronted with the measurements in a real industrial operation are presented in this case study of large spaces. It should be emphasized that the results are different if we take into account the normative boundary conditions than when calculating using the simulation program. These are also differences when considering a furnished and unfurnished interior. Any situation of preliminary determination of equipment and built-in elements in the interior will be represented by other conditions, and only the calculated results will be indicative. They come closer to the values we can expect in a real interior.

The contribution shows the possibility of $D F$ approximation when using windows. In residential buildings, the windows are approximately $10 \%$ of the floor area. In an industrial setting, especially in industrial buildings or other large-spaced indoor areas, it is about 3-6\%. For the preliminary determination of $D F$ in such cases, Equation (6) can be used.

When assessing building sustainability based on computational programs, the daylight element becomes just one of the sustainability assessment indicators. At the same time, the need for daylight is essential for sustainability and its emphasis should be highlighted in evaluation programs. Of course, it is not a simple matter to find a compromise between ecology, environment, economics, and energy requirements. However, this is the role for all of us in the future, because getting closer to sustainable development is our goal.

Acknowledgments: This paper was elaborated with the financial support of the research project VEGA 1/0674/18 of the Scientific Grant Agency, the Ministry of Education, Science, Research, and Sport of the Slovak Republic and the Slovak Academy of Sciences.

Author Contributions: Dušan Katunský coordinated the project, performed the field studies, and wrote the initial draft. Erika Dolníková conducted measurements of illuminations. Bystrík Dolník established a model for simulation and conducted daylight simulations using the simulation computer program. Dušan Katunský, Erika Dolníková, and Bystrík Dolník jointly performed analysis of the data and discussed the issues. Dušan Katunský developed the computational model and wrote the final version of the study.

Conflicts of Interest: The authors declare no conflicts of interest. 


\section{References}

1. Kontadakis, A.; Tsangrassoulis, A.; Doulos, L.; Topalis, F. An active sunlight redirection system for daylight enhancement beyond the perimeter zone. Build. Environ. 2017, 113, 267-279. [CrossRef]

2. Tsangrassoulis, A.; Doulos, L.; Santamouris, M.; Fontoynont, M.; Maamari, F.; Wilson, M.; Jacobs, A.; Solomon, J.; Zimmerman, A.; Pohl, W.; et al. On the energy efficiency of a prototype hybrid daylighting system. Sol. Energy 2005, 79, 56-64. [CrossRef]

3. Doulos, L.T.; Tsangrassoulis, A.; Kontaxis, P.A.; Kontadakis, A.; Topalis, F.V. Harvesting daylight with LED or T5 fluorescent lamps? The role of dimming. Energy Build. 2017, 140, 336-347. [CrossRef]

4. Doulos, L.; Tsangrassoulis, A.; Topalis, F. The role of spectral response of photosensors in daylight responsive systems. Energy Build. 2008, 40, 588-599. [CrossRef]

5. Bellia, L.; Fragliasso, F.; Stefanizzi, E. Why are daylight-linked controls (DLCs) not so spread? A literature review. Build. Environ. 2016, 106, 301-312. [CrossRef]

6. Bellia, L.; Pedace, A.; Fragliasso, F. The impact of the software's choice on dynamic daylight simulations' results: A comparison between daysim and 3ds max design ${ }^{\circledR}$. Sol. Energy 2015, 122, 249-263. [CrossRef]

7. Shishegar, N.; Boubekri, M. Natural light and productivity: Analyzing the impacts of daylighting on students' and workers' health and alertness. In Proceedings of the International Conference on "Health, Biological and Life Science" (HBLS-16), Istanbul, Turkey, 18-19 April 2016.

8. Friborg, O.; Rosenvinge, J.; Wynn, R.; Gradisar, M. Sleep timing, phonotype, mood, and behavior at an arctic latitude $\left(69^{\circ} \mathrm{N}\right)$. Sleep Med. 2014, 15, 798-807. [CrossRef] [PubMed]

9. McColl, S.L.; Wilkinson, F. Visual contrast gain control in migraine: Measures of visual cortical excitability and inhibition. Cephalalgia 2000, 20, 74-84. [CrossRef] [PubMed]

10. Smolders, K.C.H.J.; De Kort, Y.A.W.; Cluitmans, P.J.M. Higher light intensity induces modulations in brain activity even during regular daytime working hours. Light. Res. Technol. 2015, 48, 433-448. [CrossRef]

11. Yao, J.; Chow, D.H.C.; Chi, Y.-W. Impact of Manually Controlled Solar Shades on Indoor Visual Comfort. Sustainability 2016, 8, 727. [CrossRef]

12. Fabi, V.; Andersen, R.K.; Corgnati, S. Verification of stochastic behavioural models of occupants' interactions with windows in residential buildings. Build. Environ. 2015, 94, 371-383. [CrossRef]

13. Gou, Z.; Lau, S.S.; Ye, H. Visual alliesthesia: The gap between comfortable and stimulating illuminance settings. Build. Environ. 2014, 82, 42-49. [CrossRef]

14. Gou, Z.; Lau, S.S.; Qian, F. Comparison of mood and task performance in naturally-lit and artificially-lit environments. Indoor Built Environ. 2015, 24, 27-36. [CrossRef]

15. Amundadottir, M.L.; Lockley, S.W.; Andersen, M. Unified framework to evaluate non-visual spectral effectiveness of light for human health. Light. Res. Technol. 2017, 49, 673-696. [CrossRef]

16. Lee, J.H.; Moon, J.W.; Kim, S. Analysis of occupants' visual perception to refine indoor lighting environment for office tasks. Energies 2014, 7, 4116-4139. [CrossRef]

17. Wang, N.; Boubekri, M. Design recommendations based on cognitive, mood and preference assessments in a sunlit workspace. Light. Res. Technol. 2011, 43, 55-72. [CrossRef]

18. Yokoya, M.; Yamamoto, S.; Yamauchi, Y.; Yamamoto, S.; Ouda, O.; Nakaguchi, T.; Tsumura, N. Subjective evaluation of specular appearance for multiple observations using projector-based appearance reproduction. In International Workshop on Computational Color Imaging, 3rd ed.; Springer: Berlin/Heidelberg, Germany, 2011; Volume 6626.

19. Lee, K.S.; Han, K.J.; Lee, J.W. Feasibility Study on Parametric Optimization of Daylighting in Building Shading Design. Sustainability 2016, 8, 1220. [CrossRef]

20. Hirning, M.B.; Isoardi, G.L.; Cowling, I. Discomfort glare in open plan green buildings. Energy Build. 2014, 70, 427-440. [CrossRef]

21. Hirning, M.; Coyne, S.; Cowling, I. The use of luminance mapping in developing discomfort glare research. J. Light Vis. Environ. 2010, 34, 101-104. [CrossRef]

22. Shen, H.; Tzempelikos, A. Daylight-linked synchronized shading operation using simplified model-based control. Energy Build. 2017, 145, 200-212. [CrossRef]

23. Švajlenka, J.; Kozlovská, M.; Pošiváková, T.; Čonková, E. Indoor Analysis of Environment in Buildings. Chem. Listy 2017, 111, 398-403. 
24. Švajlenka, J.; Kozlovská, M.; Pošiváková, T. Assessment and biomonitoring indoor environment of buildings. Int. J. Environ. Health Res. 2017, 27, 427-439. [CrossRef] [PubMed]

25. Baker, N.; Steemers, K. Daylight Design of Buildings: A Handbook for Architects and Engineers; Book Routledge: Abingdon, UK, 2014; 260p, ISBN 978-1134-257-348.

26. Lyons, L.S. Handbook of Industrial Lighting; Elsevier: Amsterdam, The Netherlands, 2013; p. 224.

27. Dolníková, E.; Katunský, D. Hodnotenie Svetelnej Pohody Pri Kombinovanom Osvetl'ovacom Systéme V Priemyselných Halách; TUKE Košice: Košice, Slovakia, 2017; p. 151.

28. Kalousek, M.; Mohelníková, J. Influence of Window on Solar Gains and Daylight Level. Adv. Mater. Res. 2014, 1041, 175-179. [CrossRef]

29. Ferencikova, M.; Darula, S. Availability of daylighting in school operating time. Light Eng. 2017, 25, 71-78.

30. Moazzeni, M.H.; Ghiabaklou, Z. Investigating the influence of light shelf geometry parameters on daylight performance and visual comfort, a case study of educational space in Tehran, Iran. Buildings 2016, 6, 26. [CrossRef]

31. Krüger, E.L.; Fonseca, S.D. Evaluating daylighting potential and energy efficiency in a classroom building. J. Renew. Sustain. Energy 2011, 3, 63112. [CrossRef]

32. Piderit Moreno, M.B.; Labarca, C.Y. Methodology for assessing daylighting design strategies in classroom with a climate-based method. Sustainability 2015, 7, 880-897. [CrossRef]

33. Xue, P.; Mak, C.M.; Huang, Y. Quantification of luminous comfort with dynamic daylight metrics in residential buildings. Energy Build. 2016, 117, 99-108. [CrossRef]

34. Nebia, B.; Tabet Aoul, K. Overheating and Daylighting; Assessment Tool in Early Design of London's High-Rise Residential Buildings. Sustainability 2017, 9, 1544. [CrossRef]

35. Iringova, A. Impact of external shading on light comfort and energy efficiency in apartment buildings. Appl. Mech. Mater. 2017, 861, 485-492. [CrossRef]

36. Mohsenin, M.; Hu, J. Assessing daylight performance in atrium buildings by using Climate Based Daylight Modeling. Sol. Energy 2015, 119, 553-560. [CrossRef]

37. Berardi, U.; Anaraki, H.K. The benefits of light shelves over the daylight illuminance in office buildings in Toronto. Indoor Built Environ. 2016, 27, 244-262. [CrossRef]

38. Gonzalez, J.; Fiorito, F. Daylight design of office buildings: Optimisation of external solar shadings by using combined simulation methods. Buildings 2015, 5, 560-580. [CrossRef]

39. Pellegrino, A.; Cammarano, S.; Verso, V.R.; Corrado, V. Impact of daylighting on total energy use in offices of varying architectural features in Italy: Results from a parametric study. Build. Environ. 2017, 113, 151-162. [CrossRef]

40. Costanzo, V.; Donn, M. Thermal and visual comfort assessment of natural ventilated office buildings in Europe and North America. Energy Build. 2017, 140, 210-223. [CrossRef]

41. Konis, K. Evaluating daylighting effectiveness and occupant visual comfort in a side-lit open-plan office building in San Francisco, California. Build. Environ. 2013, 59, 662-677. [CrossRef]

42. Mistrick, R.; Casey, C.; Chen, L.; Sarith Subramaniam, S. Computer modeling of daylight-integrated photocontrol of electric lighting systems. Buildings 2015, 5, 449-466. [CrossRef]

43. Nasrollahi, N.; Shokri, E. Daylight illuminance in urban environments for visual comfort and energy performance. Renew. Sustain. Energy Rev. 2016, 66, 861-874. [CrossRef]

44. Reinhart, C.F.; Wienold, J. The daylighting dashboard-A simulation-based design analysis for daylit spaces. Build. Environ. 2011, 46, 386-396. [CrossRef]

45. Amorim, R.; López, J.C.; Molina-Moreno, V.; Peña-García, A. Use of Natural Light vs. Cold LED Lighting in Installations for the Recovery of Victims of Gender Violence: Impact on Energy Consumption and Victims' Recovery. Sustainability 2017, 9, 562. [CrossRef]

46. Shen, E.; Hu, J.; Patel, M. Energy and visual comfort analysis of lighting and daylight control strategies. Build. Environ. 2014, 78, 155-170. [CrossRef]

47. Uriarte, U.; Hernández, R.J.; Zamora, J.L.; Isalgue, A. Side-view atmospheres under outdoor midday high luminance. Buildings 2016, 6, 53. [CrossRef]

48. Gunay, H.B.; O’Brien, W.; Beausoleil-Morrison, I.; Gilani, S. Development and implementation of an adaptive lighting and blinds control algorithm. Build. Environ. 2017, 113, 185-199. [CrossRef]

49. Jia, L.; Afshari, S.; Mishra, S.; Radke, R.J. Simulation for pre-visualizing and tuning lighting controller behavior. Energy Build. 2014, 70, 287-302. [CrossRef] 
50. Doulos, L.; Tsangrassoulis, A.; Topalis, F. Multi-criteria decision analysis to select the optimum position and proper field of view of a photosensor. Energy Convers. Manag. 2014, 86, 1069-1077. [CrossRef]

51. Doulos, L.; Tsangrassoulis, A.; Topalis, F. Quantifying energy savings in daylight responsive systems: The role of dimming electronic ballasts. Energy Build. 2008, 40, 36-50. [CrossRef]

52. Veitch, J.A.; Whitehead, L.A.; Mossman, M.; Pilditch, T.D. Chromaticity-matched but spectrally different light source effects on simple and complex color judgments. Color Res. Appl. 2014, 39, 263-274. [CrossRef]

53. Perez, R.; Seals, R.; Michalsky, J. All weather model for sky luminance distribution-Preliminary configuration and validation. Sol. Energy 1993, 50, 235-245. [CrossRef]

54. Igawa, N.; Koga, Y.; Matsuzawa, T.; Nakamura, H. Models of sky radiance distribution and sky luminance distribution. Sol. Energy 2004, 77, 137-157. [CrossRef]

55. Katunský, D. Aproximatívny výpočet minimálnych činitel'ov dennej osvetlenosti vo ve'korozmerových priemyslových halách. Build. Res. J. 1992, 40, 299-311.

56. Van Bommel, W.J.M.; van den Beld, G.J. Lighting for work: A review of visual and biological effects. Light. Res. Technol. 2004, 36, 255-269. [CrossRef]

57. Yan, B.; Long, E.; Meng, X.; Zhang, Y.; Hou, D.; Du, X. Influence of user behavior on unsatisfactory indoor thermal environment. Energy Convers. Manag. 2014, 86, 1-7. [CrossRef]

58. Sokol, N.; Martyniuk-Peczek, J. The review of the selected challenges for an incorporation of daylight assessment methods into urban planning in Poland. Procedia Eng. 2016, 161, 2191-2197. [CrossRef]

59. Chen, K.W.; Norford, L. Evaluating Urban Forms for Comparison Studies in the Massing Design Stage. Sustainability 2017, 9, 987. [CrossRef]

60. Labat, M.; Attonaty, K. Numerical estimation and sensitivity analysis of the energy demand for six industrial buildings in France. J. Build. Perform. Simul. 2017, 3, 1-21. [CrossRef]

61. Gourlis, G.; Ivacic, I. A study on building performance analysis for energy retrofit of existing industrial facilities. Appl. Energy 2016, 184, 1389-1399. [CrossRef]

62. Pham, K.; Garcia-Hansen, V.; Isoardi, G. Appraisal of the Visual Environment in an Industrial Factory: A Case Study in Subtropical Climates, Solarlits. J. Daylighting 2016, 3, 12-26. [CrossRef]

63. Alarcon, B.; Aguado, A.; Manga, R.; Josa, A. A value function for assessing sustainability application to industrial buildings. Sustainability 2011, 3, 35-50. [CrossRef]

64. Katunsky, D.; Dolnikova, E.; Doroudiani, S. Integrated Lighting Efficiency Analysis in Large Industrial Buildings to Enhance Indoor Environmental Quality. Buildings 2017, 7, 47. [CrossRef]

65. Lombera, J.T.; Rojo, J.C. Industrial building design stage based on a system approach to their environmental sustainability. Constr. Build. Mater. 2010, 24, 438-447. [CrossRef]

66. Lombera, J.-T.S.-J.; Aprea, I.G. A system approach to the environmental analysis of industrial buildings. Build. Environ. 2010, 45, 673-683.

67. Standards ČSN 360020. Integral Lighting; CZ Office of Standards, Metrology and Testing Prague: Prague, Czech Republic, 2015.

68. Standards STN 730580. Daylighting in Buildings, Part-1 Basic Requirements, 1986 Part-2; Daylighting of Residential Buildings; Slovak Republic Office of Standards, Metrology and Testing: Bratislava, Slovakia, 2000.

69. Standards EN 12464-1:2012. Light and Lighting; Lighting of Work Places-Part. 1: Indoor Work Places; Slovak Republic Office of Standards, Metrology and Testing: Bratislava, Slovakia, 2012.

70. Draft Standards CEN/TC/ 169/WG 11, 07/2017. EN 17037 Daylight in Buildings (TC169WI00169068); European Committe for Standardization: Brussels, Belgium, 2017.

71. International Energy Agency (IEA). Solar and Heating Cooling Program, Task 31-Daylighting Buildings in the 21st Century; IEA: Paris, France; Available online: http:/ / task31.iea-shc.org/ (accessed on 2 May 2017).

(C) 2018 by the authors. Licensee MDPI, Basel, Switzerland. This article is an open access article distributed under the terms and conditions of the Creative Commons Attribution (CC BY) license (http:/ / creativecommons.org/licenses/by/4.0/). 